\title{
USING GIS METHODS FOR MODELLING EXCEPTIONAL FLOOD EVENTS IN BASEU RIVER BASIN, NE ROMANIA
}

DOI: http://dx.doi.org/10.18509/GBP.2018.51

UDC: 004:528.8/.9]:627.516(498)

\author{
Andrei Urzica1, \\ Alin Mihu-Pintilie ${ }^{2}$, \\ Elena Hutanu', \\ Bogdan Vasile Ghindaoanu, \\ Liviu Marian Albu ${ }^{1}$ \\ ${ }^{1}$ Alexandru Ioan Cuza University of Iasi, Faculty of Geography and Geology, Department of \\ Geography, Bd. Carol I 20A, 700505, Iasi, Romania \\ ${ }^{2}$ Interdisciplinary Research Department, Field Science, Alexandru Ioan Cuza University of Iasi, \\ St. Lascar Catargi 54, RO-700107 Iasi, Romania
}

\begin{abstract}
The Baseu catchment basin is situated in the northeast of Romanian and it is a right-side tributary of the Prut River. At the end of spring the most significant floods occur on the Romanian territory. They are due to the maximum amounts of rainfall and to snow melting. The phenomenon is also specific to the Baseu catchment basin. The last 20 years have witnessed a change in temporal manifestation, with maximum intensities during the summer (the months of July and August) when heavy rainfall is recorded. In the last 40 years, several critical episodes occurred, which endangered the lives of 79,000 inhabitants. In order to assess the hazard associated with maximum runoff, a floodable stripe with an assurance of $1 \%$ (once every 100 years) was modelled. Flood modelling involved the manipulation in GIS setting of the parameters of digital elevation model (DEM) and of their relations with the hydrological system. The main objective of the study is the modelling of an exceptional flood with a probability of $1 \%$, similar to the one of 1969 , when the Stefanesti gauging station recorded a flow of $330 \mathrm{~m}^{3} / \mathrm{s}$. Based in the analysis of the hydrological data spanning over 50 years, recorded at three gauging stations, a maximum flow of $248.1 \mathrm{~m}^{3} / \mathrm{s}$ was determined (the Stefanesti gauging station), using the Pearson III probability curve. The findings have highlighted the significant vulnerability of the human settlements situated in the flood plain of the Baseu River. A surface of 17,000 ha would be flooded, accounting for around $17.5 \%$ of the total basin surface.
\end{abstract}

Key words: major riverbed, historic floods, probability, land use, wetlands

\section{INTRODUCTION}

Under hydrological aspect Romania is facing starting with the second half of the cold season until the beginning of the warm season with exceptional flood situations caused by sudden melting of snow and heavy rain. The main causes of the floods occurring in Romania are the combination of several types of anthropogenic activities such as: uncontrolled deforestation, favouring the reduction of interception, retention and infiltration, while emphasizing the erosion of land in the slope; building houses and industrial buildings in the floodplain area; building embankments in the meadow 
overlapping communication routes and barging rivers, reducing their active drainage section. At the regional level, north-eastern Romania frequently faces floods as a consequence of its location between two large hydrographical basins, Siret basin that is predominantly mountainous and Prut catchment specific to the hillside and plain [1-7].

The Baseu River basin has faced many hydrological critical situations over time which was recorded in the national literature. Under historical aspect, the situations worth mentioning from the point of view of the magnitude of the phenomenon are those of 1932 when the union of the waters of the Baseu River with those of the Prut River flooded the meadow at a width of 2-3 km and that of 1969 when the most violent flood in the history of the basin hydrographic basin, with a duration between $65-125$ hours and a maximum flow of $330 \mathrm{~m}^{3} / \mathrm{s}$, was recorded on the basis of abundant rainfall. The importance of identifying areas with a high potential flood risk derives from the need to reduce the devastating effects of floods, which can be of an economic, social and environmental nature. The present paper aims to achieve two objectives: the application of the flood modeling methodology using the HEC-RAS software based on high resolution digital terrain model (LiDAR) and spatial analysis of floods with probability of occurrence of $0.1 \%, 1 \%$ and $3 \%$.

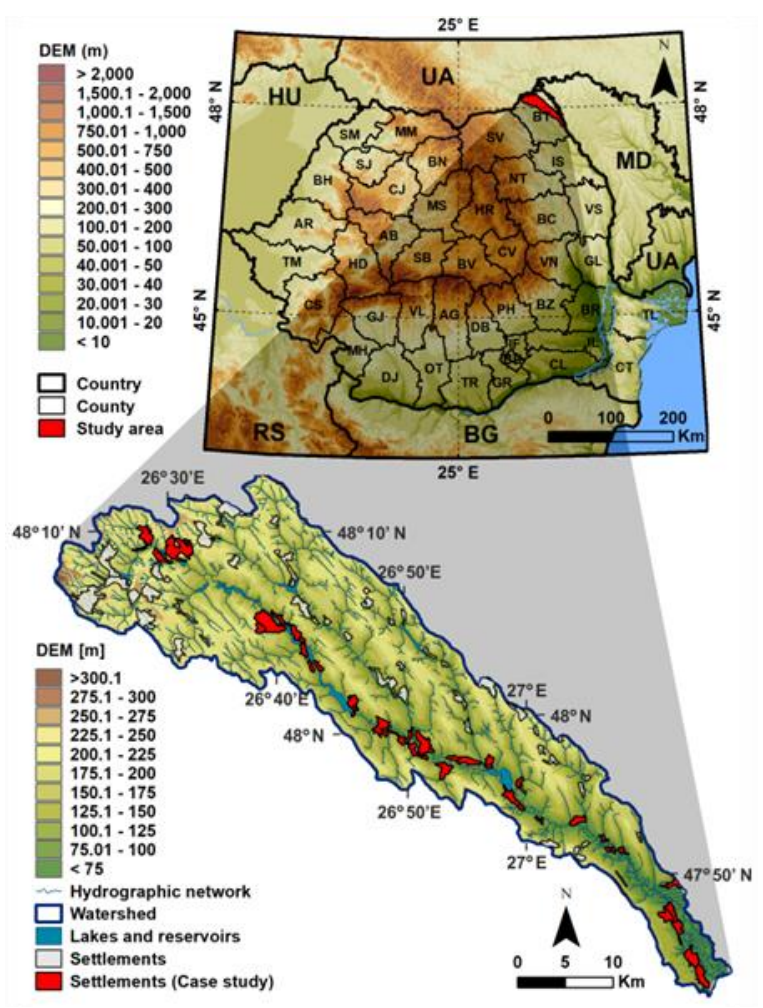

Figure 1. Geographical location of the study area on Romania territory

So far, studies focusing on modeling floods using GIS techniques and estimating the damage generated by them for the Baseu River basin are based only on modeling within institutions and their display on web platforms. These modeling have been part of the process of implementing the 2007/60/CE Directive, which has as main objective the assessment and management of flood risk. At the same time, at the local level, was generated a flood band on a scale of 1:25000, elaborated by the Technical Support Group of CJSU Botosani. Recent studies dealing with hydrological risks and their modeling in 
hydrographic basins in the mountain and sub-mountain area belong to the authors such as:[7-9].The international literature that has been assimilated for this study [9-26].

\section{STUDY AREA}

The Baseu river flows in the north-east of Romania its river basin Baseu river basin is located in the northeastern part of Romania, being a component of Moldavian Plain in proportion of $90 \%$, and the Suceava Plateau in proportion of $10 \%$, represented by the central-eastern part of Ibanesti Hill (Figure 1). It has a length of $118 \mathrm{~km}$, and it drains an area of $967 \mathrm{~km}^{2}$. The altitude of the Baseu catchment varies between $54 \mathrm{~m}$ in the river meadow, in the southern part, at the confluence of the Baseu River with the Prut River and $318 \mathrm{~m}$ in the extreme north. It has a seasonal rich drain with an underground feed of $30-40 \%$ [1-4].

The multi-annual average flow rate at the Stefanesti hydrometric station between the years $1966-2016$ is $1.6 \mathrm{~m}^{3} / \mathrm{s}\left(Q_{\text {avg }}=6.9 \mathrm{~m}^{3} / \mathrm{s}\right.$ in $1969 ; Q_{\text {avg }}=0.1 \mathrm{~m}^{3} / \mathrm{s}$ in 2016). The temperature of the air shows a small variation from the north to the southern part, the thermal regime being determined to a large extent by the thermal characteristics of the air masses. Average air temperature values are between $7.7^{\circ} \mathrm{C}$ and $9.6^{\circ} \mathrm{C}$. Annual average precipitation ranges from 450 to $624 \mathrm{~mm}$. From the point of view of land use, the Baseu catchment is occupied in a proportion of $66 \%$ of arable land, $21 \%$ of pastures, $5 \%$ of forests, $2.8 \%$ yards and constructions, $2.1 \%$ of water surfaces, $1.7 \%$ of vegetation forestry and $1.4 \%$ other structures.

\section{METHODS}

The High Resolution Digital Model (LiDAR) and the hydrological data were provided by the Regional Water Administration Prut-Barlad, Iasi. To this dataset allowed the determination of maximum flows using the Pearson Type III distribution curve. The three hydrometric stations used in this study are situated in the upper, middle and lower sectors of the Baseu River. Determination of flows corresponding to the probabilities of occurrence of $0.1 \%, 1 \%$ and $3 \%$ implied statistical calculations based on the flows recorded at the three hydrometric stations within the river basin (Table 1) [8, 14-15]. The calculations consisted in determining the probability of empirical overflow according to Weibull's formula (1.1) and the probability of occurrence of unregistered flows based on the calculation formula Person III (1.2) [8].

(1.1.) $\mathrm{Pi}=\mathrm{i} /(\mathrm{n}+1)^{*} 100$

Where: $\mathrm{Pi} \%$-the probability of the occurrence of a measured flow; $\mathrm{i}$-the order number of the flow rate; $\mathrm{n}$-the total number of string terms;

(1.2.) $\mathrm{Qp} \%=\mathrm{Qmed} *\left(1+\mathrm{Cv}^{*} \Phi \mathrm{p} \%\right)$

Where: $\mathrm{Qp}$ - insurance flow rate; Qmed - average flow rate; $\mathrm{Cv}$ - the coefficient of variation; $\Phi \mathrm{p} \%$ - ordinates of the insurance curve for $\mathrm{Cv}=1$.

Table 1. The maximum flow rates and the exceedance with different probabilities on the Başeu River

\begin{tabular}{llllccccc}
\hline & & & & \multicolumn{4}{c}{ Max. flow rates with different exceedance } \\
& & & $Q_{\max }$ & \multicolumn{4}{c}{ probabilities** } \\
\cline { 5 - 9 } River & Gauge type* & Date & $\left(\mathrm{m}^{3} / \mathrm{s}\right)$ & $0.1 \%$ & $1 \%$ & $3 \%$ & $5 \%$ & $10 \%$ \\
\hline Başeu & ${ }_{\mathrm{s}}$ G1 Havârna & July 1969 & 143 & 203 & 113 & 74 & 55 & 34 \\
& ${ }_{\mathrm{s}}$ G2 Ştiubeni & May 1985 & 22.6 & 117 & 66 & 44 & 33 & 21 \\
& ${ }_{\mathrm{m} \text { G3 Ştefăneşti }}$ & July 1969 & 330 & 431 & 248 & 167 & 130 & 85 \\
\hline
\end{tabular}


* ${ }_{\mathrm{s}} \mathrm{G}$ - secondary gauge $\left({ }_{\mathrm{s}} \mathrm{G} 1\right.$ Havârna - recorded period 1969-2000; ${ }_{\mathrm{s}} \mathrm{G} 2$ Ştiubei - recorded period 19801997); $\mathrm{mG}$ - Main gauge (mG3 Ştefăneşti - recorded period 1966-2016). **The maximum flow rates with different exceedance probabilities were estimated using the Pearson Type III distribution curve, taking into account the historical flow rates recorded at the G1 and G3 in July 1969, and at the G2 in May 1985.

In obtaining areas exposed to flood risk was used HEC-RAS (Hydrologic Engineering Centers River Analysis System) software, developed by the US Army Corps of Engineers in 1993 [14, 15]. Also it was used the ArcGis software and the HEC-Geo-RAS extension. In order to model flood risk for the area under consideration, three stages were carried out: pre-processing, processing and eventually post-processing. The pre-processing stage involves creating necessary vectors such as: riverbed, banks, flow paths and the crosssections [8].

The next step is to calculate the attributes that are necessary to generate the flood bands in the second stage (length, hydro-ID, station, river name, reach, banks, left/right length, channel length). The processing step involves exporting to the HEC-RAS software and introducing some parameters such as: Manning roughness coefficient and Boundary condition. The post-processing step involves exporting the HEC-RAS result to the ArcGis software and achieving the flood limit for the $0.1 \%, 1 \%$ and $3 \%$ situations.

Table 2. Flooded area with different probabilities and the population from Baseu river meadow

\begin{tabular}{|c|c|c|c|c|c|c|c|c|}
\hline \multirow[b]{2}{*}{ Code } & \multirow[b]{2}{*}{ Settlement } & \multirow{2}{*}{$\begin{array}{c}\text { Surface } \\
\left(\mathrm{km}^{2}\right)\end{array}$} & \multirow{2}{*}{$\begin{array}{l}\text { Population } \\
\text { (no.ppl) }\end{array}$} & \multirow{2}{*}{$\begin{array}{l}\text { Ppl. density } \\
\left(\mathrm{ppl} / \mathrm{km}^{2}\right)\end{array}$} & \multicolumn{4}{|c|}{ Flooded area (Ha) with different probabilities } \\
\hline & & & & & $\begin{array}{c}\text { HEC-RAS } \\
0.1 \%\end{array}$ & $\begin{array}{c}\text { HEC-RAS } \\
1 \%\end{array}$ & $\begin{array}{c}\text { HEC-RAS } \\
3 \%\end{array}$ & $\begin{array}{c}\text { CSDAF } \\
1 \%\end{array}$ \\
\hline S1 & Alba & 3.58 & 1,406 & 393 & 57.17 & 49.11 & 41.78 & 33.01 \\
\hline $\mathbf{S 2}$ & Bașeu & 1.08 & 539 & 499 & 17.6 & 7.44 & 6.25 & 3.57 \\
\hline S3 & Hudești & 2.75 & 1,100 & 400 & 9.75 & 5.47 & 4.25 & 5.11 \\
\hline S4 & Havârna & 4.18 & 2,823 & 675 & 15.75 & 10.99 & 8.58 & 2.41 \\
\hline S5 & Gârbeni & 0.64 & 420 & 656 & 16.33 & 12.65 & 10.87 & 1.11 \\
\hline S6 & Tătărășeni & 1.14 & 797 & 699 & 17.93 & 12.76 & 10.03 & 7.12 \\
\hline S7 & Balinți & 0.67 & 396 & 591 & 14.23 & 12.01 & 10.13 & 7.74 \\
\hline S8 & Niculcea & 0.13 & 41 & 315 & 0.51 & 0.35 & 0.27 & 0.15 \\
\hline S9 & Negreni & 1.09 & 909 & 834 & 5.49 & 4.58 & 4.12 & 3.93 \\
\hline S10 & Ştiubieni & 2.14 & 1,727 & 807 & 13.01 & 7.37 & 5.06 & 1.97 \\
\hline S11 & Chișcăreni & 0.61 & 495 & 811 & 7.77 & 5.78 & 4.80 & 1.62 \\
\hline S12 & Sat Nou & 0.28 & 124 & 443 & 10.08 & 9.53 & 7.36 & - \\
\hline S13 & Petricani & 0.97 & 645 & 665 & 23.84 & 21.12 & 17.90 & 2.57 \\
\hline S14 & Săveni & 2.29 & 8,145 & 3,557 & 16.16 & 8.24 & 4.37 & 5.12 \\
\hline S15 & Vlăsinești & 1.56 & 1,596 & 1,023 & 13.13 & 7.54 & 4.60 & 0.05 \\
\hline S16 & Bozieni & 0.34 & 255 & 750 & 9.96 & 7.80 & 6.87 & 2.38 \\
\hline S17 & Sârbi & 1.04 & 1,064 & 1,023 & 14.95 & 12.23 & 9.61 & 1.07 \\
\hline S18 & Miron C. & 0.83 & 472 & 569 & 5.35 & 4.73 & 4.53 & 0.90 \\
\hline S19 & Slobozia & 0.18 & 86 & 478 & 3.24 & 1.47 & 0.33 & 2.14 \\
\hline $\mathbf{S 2 0}$ & Hănești & 1.28 & 1,127 & 880 & 22.64 & 14.14 & 9.96 & 8.86 \\
\hline S21 & Moara J. & 0.22 & 89 & 405 & 3.91 & 1.94 & 0.76 & 0.67 \\
\hline S22 & Mihălășeni & 1.07 & 743 & 694 & 1.73 & 0.60 & 0.22 & 1.62 \\
\hline $\mathbf{S 2 3}$ & Negrești & 0.32 & 300 & 938 & 1.44 & 0.58 & 0.23 & 2.87 \\
\hline S24 & Păun & 0.41 & 289 & 705 & 23.17 & 9.57 & 6.04 & 6.97 \\
\hline $\mathbf{S} 25$ & Năstase & 0.31 & 183 & 590 & 3.14 & 2.00 & 1.55 & 0.32 \\
\hline S26 & Stânca & 1.05 & 812 & 773 & 15.13 & 11.23 & 8.59 & - \\
\hline S27ab & Ștefănești & 2.42 & 6,630 & 2,740 & 15.26 & 11.25 & 9.69 & - \\
\hline S28 & Bădiuți & 1.08 & 985 & 912 & 47.85 & 44.60 & 42.63 & - \\
\hline S29 & Bobulești & 2.06 & 1,322 & 642 & 15.68 & 7.10 & 4.28 & 0.38 \\
\hline S30 & Românești & 1.83 & 1,394 & 762 & 29.03 & 20.56 & 15.05 & 6.06 \\
\hline
\end{tabular}




\section{RESULTS AND DISCUSSION}

By analyzing the results of the three specific situations, the probability of occurrence of maximum flood-generating flows was highlighted by the high exposure of localities to floods with a probability of production once every 1000 years, 100 years and 33 for years. With regard to the flooded areas in Table 2, it can be seen the flooded areas for each settlement within meadow. In the case of the $0.1 \%$ situation the affected area was 18.000 ha which represent $18.6 \%$ of the entire catchment. The flood band with a probability of $1 \%$ affected a 17.000 ha, which represents $17.6 \%$ of the surface of the river basin, and the flood band with a probability of 3\%, affected an area of 16.400 ha, occupying $16.9 \%$ of the total area of the basin. Regarding the County Scheme of Defense Against Flooding (CSDAF) flood band the affected area was 16.300 ha [3].

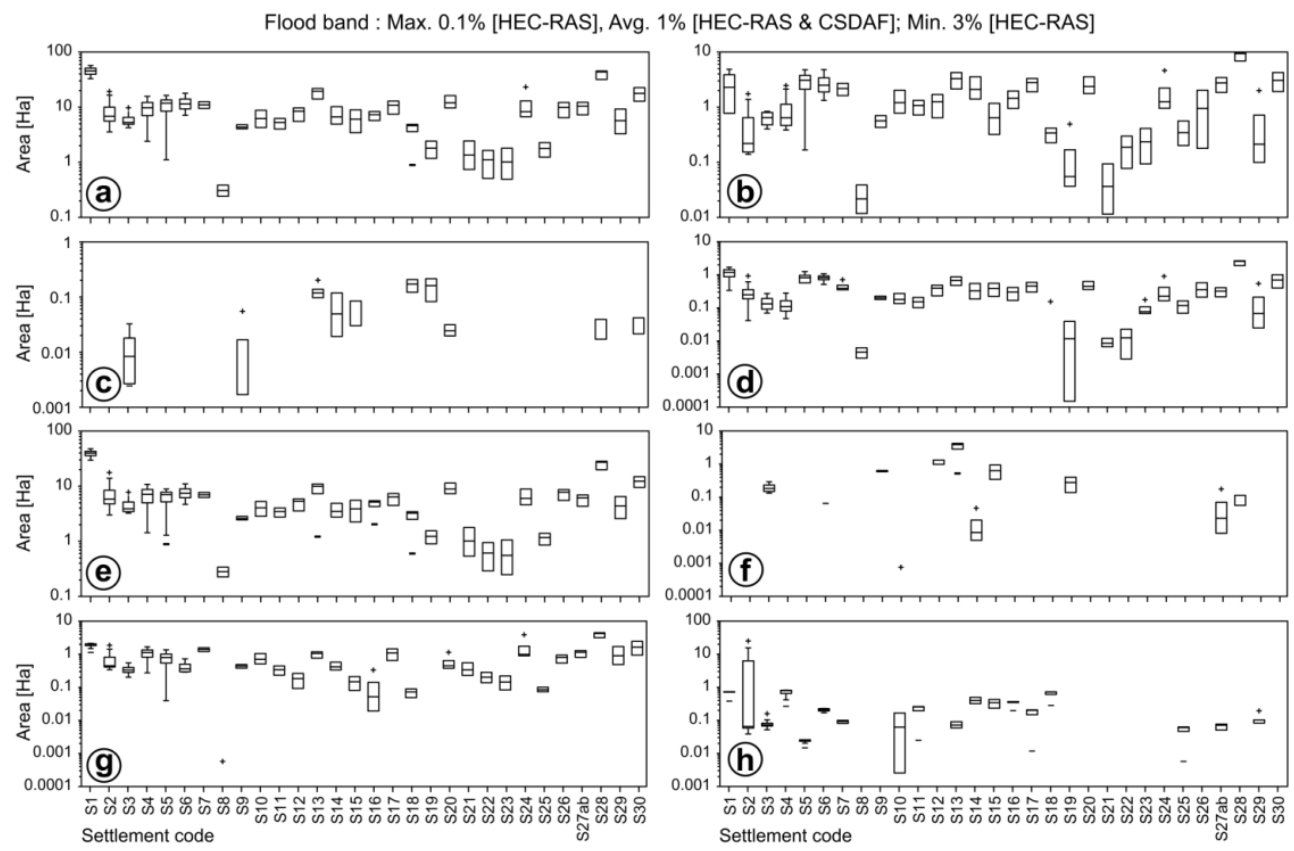

Figure 2. Boxplots showing the flood areas descriptive statistics for all settlements grouped by main land use classes: (a) total affected area, (b) residential area, (c) industrial area, (d) transport infrastructure, (e) agricultural area, (f) unproductive land, (g) forest and (h) water body.

From the point of view of land use, the polygons have been digitized after orthophotos manually and were chosen 24 classes of land use and after that were grouped in seven large categories: residential area, industrial area, transport infrastructure, agricultural area, unproductive land, forest, and water body. The most affected categories are represented by the residential area and agricultural area. A clear situation about the affected category at the level of each settlement is offered by the Figure 2 who represents the minimum, maximum and mean values of the affected area.

Cartographically we can see the difference between the three flood bands in Figure 3 where are represented all 31 settlements of meadow Baseu river. The construction of houses predominantly in the meadow of the river favors the increase of flooded houses and implicitly of socio-economic damages. 


\section{CONCLUSIONS}

The study sought to apply a methodology for identifying areas with high hydrological risk in a medium-sized river basin. The geographic context underlying the flood phenomenon was analyzed using ArcGIS, HEC-RAS software and three hypothetical hypotheses were generated after calculating flows with a probability of occurrence of $0.1 \%, 1 \%$ and $3 \%$. The created models have highlighted the fact that a large percentage of the surface of the basin is constantly subject to flood risk, the flood band of $0.1 \%$ flooding an area of over 18.000 ha; the flood band of $1 \%$ flooded an area of 17.000 ha, while the $3 \%$ flooded the basin on an area of 16.400 ha.

The study area is predisposed to flooding as a consequence of natural conditions, in this case climate events (solid precipitation in the winter which causes by melting, floods in the second part of the cold season, heavy rainfall in the warm season) but also as a consequence of the human footprint, with regard to massive deforestation and technically unsuitable hydro-technical constructions. 


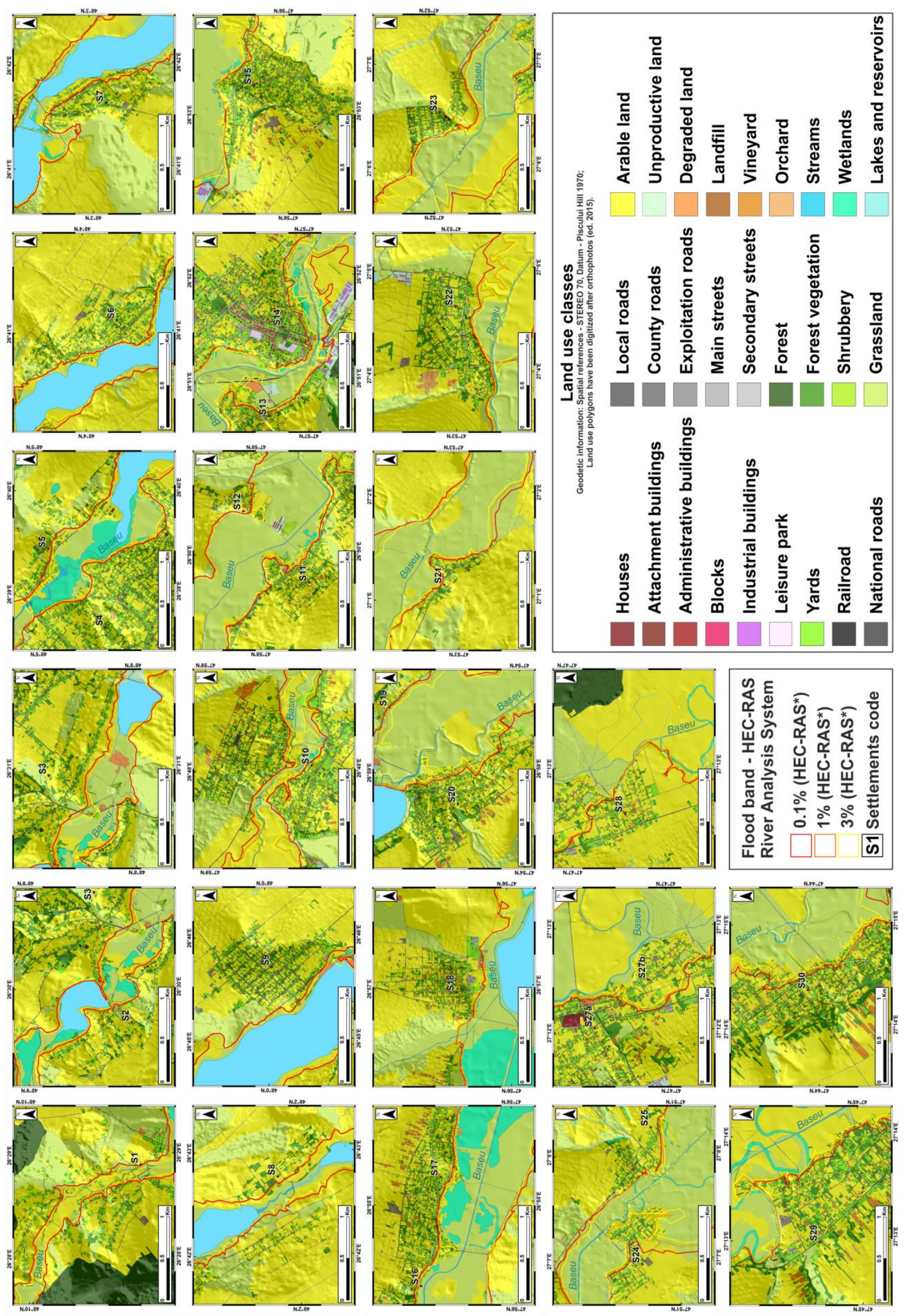

Figure 3. Example of 31 flooded settlements within Baseu catchment based on flood bands probabilities with insurance of $0,1 \%, 1 \%$ and $3 \%$ calculated using HEC-RAS River Analysis System. Conforming to land use, the damages are significant (see Figure 2). 


\section{REFERENCES}

[1] Romanescu G., Stoleriu C.C. \& Romanescu A.M, Water reservoirs and the risk of accidental flood occurrence. Case study: Stanca-Costeşti reservoir and the historical floods of the Prut river in the period July-August 2008, Romania, Hydrological Processes, United States, vol. 25, pp. 2056-2070, 2011.

[2] Romanescu G., Zaharia C. \& Stoleriu C.C., Long-term changes in average annual liquid flow river Miletin (Moldavian Plain), Carpathian Journal and Earth Environmental Sciences, Romania, vol. 7, pp. 161-170, 2012.

[3] Romanescu G., Cimpianu C.I., Mihu-Pintilie A. \& Stoleriu C.C., Historic flood events in NE Romania (post-1990), Journal of Maps, United Kingdom, vol. 13, pp. 787-798, 2017.

[4] Romanescu G. \& Stoleriu C.C., An inter-basin backwater overflow (the Buhai Brook and the Ezer reservoir on the Jijia River, Romania), Hydrological Processes, United States, vol. 28, pp. 3118-3131, 2013.

[5] Romanescu G. \& Stoleriu C.C., Exceptional floods in the Prut basin, Romania, in the context of heavy rains in the summer of 2010, Natural Hazards and Earth System Sciences, Germany, vol. 17, pp. 381-396, 2017.

[6] Romanescu G., Jora I. \& Stoleriu C.C., The most important high floods in Vaslui river basincauses and consequences, Carpathian Journal and Earth Environmental Sciences, Romania, vol. 6, pp. 119-132, 2011.

[7] Romanescu G. \& Stoleriu C.C., Causes and effects of the catastrophic flooding on the Siret River (Romania) in July-August 2008, Natural Hazards, Netherlands, vol. 63, pp. 1351-1367, 2013.

[8] Costache R., Pravalie R., Mitof I. \& Popescu C., Flood vulnerability assessment in the low sector of Sărețel cathement. Case study: Joseni village, Carpathian Journal and Earth Environmental Sciences, Romania, vol. 10, pp. 161-169, 2015.

[9] Romanescu G., Cotiuga V., Asandulesei A. \& Stoleriu C., Use of the 3-D scanner in mapping and monitoring the dynamic degradation of soils. Case study of the Cucuteni-Baiceni Gully on the Moldavian Plateau (Romania). Hydrology and Earth System Sciences, Germany, vol. 16, pp. 953-966, 2012.

[10] Marks K. \& Bates P., Integration of high-resolution topographic data with floodplain flow model, Hydrological Processes, United States, vol. 14, pp. 2109-2122, 2000.

[11] Hufschmidt G., Crozier M. \& Glade T., Evolution of natural risk: research framework and perspectives, Natural Hazards and Earth System Sciences, Germany, vol. 5, pp. 375-387, 2005.

[12] Merwade V., Cook A. \& Coonrod J., GIS techniques for creating terrain models for hydrodynamic modeling and flood mapping, Environmental Modelling \& Software, Netherlands, vol. 23, pp. 1300-1311, 2008.

[13] Koivumäki L., Alho P., Lotsari E., Käyhkä J., Saari A. \& Hyyppä H., Uncertainties in flood risk mapping: a case study on estimating building damages for a river flood in Finland, Journal of Flood Risk Management, Denmark, vol. 3, pp. 166-183, 2010.

[14] Kourgialas N. \& Karatzas G., Flood management and a GIS modeling method to assess flood-hazard areas - a case study, Hydrological Sciences Journal, United Kingdom, vol. 56, pp. 212-225, 2011.

[15] Patel C.G. \& Gundaliya P.J., Floodplain delineation using HEC-RAS model - A case study of Surat city, Open Journal of Modern Hydrology, United States, vol. 6, pp. 34-42, 2016.

[16] Romanescu G., Dinu C., Radu A. \& Torok L., Ecologic characterization of the fluviatile limans in the south-west Dobrudja and their economic implications (Romania), Carpathian Journal of Earth and Environmental Sciences, Romania, vol. 5, pp. 25-38, 2010. 
[17] Romanescu G., Cretu M.A., Sandu I.G., Paun E. \& Sandu I., Chemism of Streams Within the Siret and Prut Drainage Basins, Water Resources and Management. Rev. Chim. (Bucharest), Romania, vol. 64, pp. 1416-1421, 2013.

[18] Romanescu G. \& Stoleriu C., Anthropogenic interventions and hydrological-risk phenomena in the fluvial-maritime delta of the Danube (Romania), Ocean \& Coastal Management, United Kingdom, vol. 102, pp. 123-130, 2014.

[19] Romanescu G., \& Nistor I., The effect of the July 2005 catastrophic inundations in the Siret River's Lower Watershed, Romania, Natural Hazards, Netherlands, vol. 57, pp. 345-368, 2011.

[20] Romanescu G. \& Nicu C., Risk maps for gully erosion processes affecting archaeological sites in Moldavia, Romania., Zeitschrift für Geomorphologie, Germany vol. 58, pp. 509-523, 2014.

[21] Radevski I. \& Gorin S., Floodplain analysis for different return periods of river Vardar in Tikvesh valley (Republic of Macedonia), Carpathian Journal of Earth and Environmental Sciences, Romania, vol. 12, pp. 179-187, 2017.

[22] Andronache I., Fensholt R., Ahammer H., Ciobotaru A-M., Pintilii R-D., Peptenatu D., Drăghici C.C., Diaconu D.C., Radulović M., Pulighe G., Azihou A.F., Toyi M.S. \& Sinsin B., Assessment of textural differentiations in forest resources in Romania using fractal analysis, Forests, Switzerland, 8(3), 54, 2017. doi: 10.3390/f8030054.

[23] Diaconu D.C., Andronache I., Ahammer H., Ciobotaru A.M., Zelenakova M., Dinescu R., Pozdnyakov A.V. \& Chupikova S.A., Fractal drainage model - a new approach to determinate the complexity of watershed, Acta Montanistica Slovaca, Czech Republic, vol. 22, pp. 12-21, 2017.

[24] Zelenáková M., Fijko R., Diaconu D.C. \& Remenáková I., Environmental Impact of Small Hydro Power Plant-A Case Study, Environments, Switzerland, vol. 5, pp. 1-10, 2018.

[25] Tošić R., Lovrić N., Dragićević S. \& Manojlović S., Assessment of torrential flood susceptibility using GIS matrix method: case study - VRBAS river basin (B\&H). Carpathian Journal of Earth and Environmental Sciences, Romania, vol. 13, pp. 369-382, 2018.

[26] Wrzesiński D., Choiński A., Ptak M. \& Skowron R., Effect of the North Atlantic Oscillation on the Pattern of Lake Ice Phenology in Poland, Acta Geophysica, Germany, vol. 63, pp. 1664$1684,2015$. 